\title{
Comparative efficacy of two poeciliid fish in indoor cement tanks against chikungunya vector Aedes aegypti in villages in Karnataka, India
}

Susanta K Ghosh ${ }^{2 *}$, Preethi Chakaravarthy ${ }^{2}$, Sandhya R Panch², Pushpalatha Krishnappa ${ }^{2}$, Satyanarayan Tiwari ${ }^{1}$, Vijay P Ojha', Manjushree $\mathrm{R}^{3}$ and Aditya P Dash ${ }^{4}$

\begin{abstract}
Background: In 2006, severe outbreaks of Aedes aegypti-transmitted chikungunya occurred in villages in Karnataka, South India. We evaluated the effectiveness of combined information, education and communication (IEC) campaigns using two potential poeciliid larvivorous fish guppy (Poecilia reticulata) and mosquitofish (Gambusia affinis), in indoor cement tanks for Aedes larval control.

Methods: Trials were conducted in two villages (Domatmari and Srinivaspura) in Tumkur District from March to May 2006 for Poecilia and one village (Balmanda) in Kolar District from July to October 2006 for Gambusia. A survey on knowledge, attitude and practice (KAP) on chikungunya was initially conducted and IEC campaigns were performed before and after fish release in Domatmari (IEC alone, followed by IEC + Poecilia) and Balmanda (IEC + Gambusia). In Srinivaspura, IEC was not conducted. Larval surveys were conducted at the baseline followed by oneweek and one-month post-intervention periods. The impact of fish on Aedes larvae and disease was assessed based on baseline and post-intervention observations.

Results: Only $18 \%$ of respondents knew of the role of mosquitoes in fever outbreaks, while almost all $(n=50$ each) gained new knowledge from the IEC campaigns. In Domatmari, IEC alone was not effective (OR 0.54; $p=$ 0.067). Indoor cement tanks were the most preferred Ae. aegypti breeding habitat (86.9\%), and had a significant impact on Aedes breeding (Breteau Index) in all villages in the one-week period ( $p<0.001$ ). In the one-month period, the impact was most sustained in Domatmari (OR 1.58, $p<0.001)$ then Srinivaspura (OR 0.45, $p=0.063$ ) and Balmanda (OR 0.51, $p=0.067$ ). After fish introductions, chikungunya cases were reduced by $99.87 \%$ in Domatmari, $65.48 \%$ in Srinivaspura and $68.51 \%$ in Balmanda.
\end{abstract}

Conclusions: Poecilia exhibited greater survival rates than Gambusia (86.04 vs.16.03\%) in cement tanks. Neither IEC nor Poecilia alone was effective against Aedes $(p>0.05)$. We conclude that Poecilia + IEC is an effective intervention strategy. The operational cost was 0.50 (US\$ 0.011, 1 US\$ $\$ 47)$ per capita per application. Proper water storage practices, focused IEC with Poecilia introductions and vector sanitation involving the local administration and community, is suggested as the best strategy for Aedes control.

\section{Background}

In 2006, severe outbreaks of chikungunya occurred in the villages in Karnataka, South India. Chikungunya is a rare arboviral infection transmitted by Aedes mosquitoes. It shares the same vector and geographical

\footnotetext{
* Correspondence: ghoshmrc@vsnl.net

${ }^{2}$ Bangalore Medical College and Research Institute, Bangalore-560002, Karnataka, India

Full list of author information is available at the end of the article
}

distribution as dengue fever, and has similar symptoms with the exception of incapacitated arthralgia [1]. Over a period of three decades, chikungunya outbreaks have struck the southwestern islands of the Indian Ocean region. In India, outbreaks occurred late-2005 mainly in the southwestern states and were primarily transmitted by Aedes aegypti [2]. Approximately1.4 million suspected cases were reported in 2006 and over 0.7 million cases were from Karnataka alone [3]. 
Larvivorous fish in natural habitats that feed on Anopheles larvae have been successfully used in malaria control [4], but their use in confined domestic containers against Aedes larvae has been very limited [5]. Based on our previous experience using two potential poeciliid larvivorous fish guppy (Poecilia reticulata) and mosquitofish (Gambusia affinis) for malaria control in Karnataka [4,6], we aimed to conduct two small-scale community-based feasibility studies combined with information, education and communication (IEC) to test the comparative efficacy of these fish in containing $A e$. aegypti larval infestation and reducing chikungunya. Use of Poecilia fish combined with IEC offered the most effective means of controlling Aedes mosquito populations in our study.

\section{Methods}

In brief, our studies were carried out within Karnataka in two villages (Domatmari and Srinivaspura) in Tumkur District and in one village (Balmanda) in Kolar District, affected by chikungunya. A survey on knowledge, attitude and practice (KAP) on chikungunya was initially conducted in Domatmari and Srinivaspura. IEC campaigns were performed in Domatmari and Balmanda, before and after fish introductions. Aedes larval surveys were carried out in all three villages to assess the impact of the intervention measures undertaken. Poecilia was released in Domatmari and Srinivaspura, and Gambusia in Balmanda. Fish survival was also monitored during the larval surveys. Anonymised data on chikungunya cases were collected from the respective district health offices.

\section{Study areas and the population}

Studies were conducted in two highly chikungunyaaffected districts, Tumkur and Kolar, between March and October 2006. Domatmari (population 2040; 420 households) and Srinivaspura (population 568; 114 households), under the Venkatapura (population $74,680)$ Primary Health Centre (PHC) in Pavagada taluka ${ }^{1}\left(14^{\circ} 6^{\prime} \mathrm{LN} 77^{\circ} 16^{\prime} \mathrm{LE}\right.$, average elevation of 750 masl) of Tumkur, and Balmanda (population 1342; 284 households), under the Kamasamudram (population 36,484) $\mathrm{PHC}$ in Bangarpet taluka $\left(12^{\circ} 58^{\prime} \mathrm{LN} 78^{\circ}\right.$ 12' LE, average elevation of $850 \mathrm{masl}$ ) of Kolar, were randomly selected. The study areas are dry, rocky, sandy reddish brown soils and drought prone, with low irregular rainfall $(600-800 \mathrm{~mm})$ during 60 to 72 rainy days per annum. Temperature ranges from 13 to $39^{\circ} \mathrm{C}$. Most households studied were comprised of three to six individuals, with a male to female sex ratio of 1:0.97. Agriculture is the main form of employment for the local villagers. Literacy rate varies between 58 and $72 \%$.

\section{Tumkur trial}

\section{KAP survey}

In March 2006, a KAP survey on a representative sample of 50 respondents (mean age $28 \pm 15$, range 12-68; 31 males and 19 females) was conducted in Domatmari and Srinivaspura of Tumkur District. Unprompted and pre-tested questionnaires were used for this survey.

\section{IEC campaigns}

In Domatmari, an IEC campaign on chikungunya, its treatment and management, mode of transmission and control of Aedes larvae, especially using larvivorous fish and water storage practices, was organized to determine its impact on vector abundance. A health education campaign was performed using lectures and a live demonstration of larvivorous fish feeding on mosquito larvae. Live larvae collected from households were also shown to the villagers, and maintenance of the fish within small water-storing tanks was further explained. Inter-personal communication with each household was established during each monitoring survey. Impact of the IEC campaign was assessed after one month of the trial on 50 respondents (mean age $23 \pm 11$, range 11-62; 28 males and 22 females). In Srinivaspura, no IEC activity was organised for comparison.

\section{Kolar trial}

Chikungunya outbreaks also occurred in the neighbouring Kolar District in May-June 2006. Within this district, Balmanda was one of the chikungunya-affected villages randomly selected for the Gambusia trial from July to October 2006. IEC campaigns were performed as described

above for Domatmari. IEC impact was assessed based on 50 respondents (mean age $24 \pm 12$, range 11-59; 33 males and 17 females) at the end of the trial. Gambusia was introduced after the IEC campaign.

\section{Aedes larval surveys}

At the beginning of the study, Aedes larval surveys were conducted in every fourth line-listed house at the baseline (before IEC and fish introduction) and one-week post-IEC campaigns. Repeat larval surveys were also conducted one-week and one-month after fish introduction. Larvae were collected using a white enamel bowl $(300 \mathrm{ml})$ and a torch light. A one-larva-per-container method was used for our larval survey and density perdip was further calculated. Finally, the impact of fish introduction on the Aedes larval infestation was estimated based on house index (HI), container index $(\mathrm{CI})$ and Breteau index (BI) [2].

\section{Fish release and monitoring}

Poecilia were collected from a stream near Ventakapura, whereas Gambusia were collected from a pond in Kamasamudram that was already in use in the malaria control programme [6]. For each of the selected villages, 
10-15 fish were released into each indoor cement tank. Both fish species were used for all households $(n=818)$. Poecilia were released in 482 tanks in Domatmari and 32 in Srinivaspura, whereas Gambusia in 337 tanks in Balmanda. Monitoring of fish survival was simultaneously conducted with larval surveys.

\section{Fish impact on disease}

Under the National Vector Borne Disease Control Programme, anonymised data on chikungunya cases were collected from the respective district health offices. Each office gave permission to use this data.

\section{Ethical approval}

The Institutional Ethics Committee of National Institute of Malaria Research, New Delhi provided ethical approval for the KAP survey. Community consent was obtained for the entire study, and especially fish introductions, from the local village leaders and Gram Panchayat (village-elected council) members, school teachers and a religious leader.

\section{Statistical analysis}

Frequency of breeding contribution for each habitat and the impact of fish on larval density, and responses of the IEC campaigns, were analysed using Fisher's Exact and $\chi^{2}$ tests. Larval density data were not normally distributed and were consequently subjected to a non-parametric Kruskal-Wallis test. Significance values $(p)$ for percentage differences (baseline and post-intervention) were computed using on-line Java Script tests on difference paired proportion estimates from a set of random paired observations for the intervention parameters, i.e. HI, CI and BI (http://home.ubalt.edu/ntsbarsh/Businessstat/otherapplets/PairedProp.htm). Results with a $p<$ 0.05 were considered to be statistically significant.

\section{Results}

\section{KAP survey and impact of IEC campaigns}

KAP survey results (Table 1 ) revealed that only $18 \%$ respondents understood the role of mosquitoes during fever outbreaks, and only $2 \%$ responded that controlling mosquitoes could contain these outbreaks. Two-thirds of the respondents believed that mosquitoes breed in stagnant dirty water. Almost all go to the hospital when they get fever and believed that the administered medicine would cure them. Two-thirds of households stored water in indoor cement tanks, which were cleaned less than once a week, and $78 \%$ of the respondents covered the water storage containers. Over half of the population protected themselves from mosquito bites using coils, fans or burning of Neem (Azadirachta indica) leaves. A few respondents (8\%) knew the role of larvivorous fish in mosquito control.

The impact of IEC on fish introductions is summarized in Table 2. Almost all people studied gained newly acquired knowledge after the IEC campaigns in
Domatmari and Balmanda villages $(p>0.001)$. People also gained knowledge that the current outbreaks were due to chikungunya transmitted by the Aedes mosquito, which breeds in clean water $(p>0.01)$. The Poecilia programme in Domatmari was more liked than the Gambusia programme in Balmanda $(p<0.001)$. The unpleasant smell caused by dead Gambusia fish in the water storage containers in Balmanda was the main draw back suggested for this programme $(p<0.001)$.

\section{Aedes larval baseline survey}

Initially, a baseline survey was carried out in all villages to determine the most potential breeding habitats for Aedes mosquitoes (Table 3). A total of 456 containers in 231 households were surveyed in all of the studied villages. Percentage breeding contribution indicated indoor cement tanks supported maximal larval breeding [86.9\%, relative risk (RR) $8.2, \chi^{2} 6.74, p<0.001$ ] followed by earthen pots $\left(16.8 \%\right.$, RR 6.7, $\left.\chi^{2} 8.23, p<0.001\right)$, outdoor cement tanks $\left(8.0 \%, \mathrm{RR} 3.2, \chi^{2} 8.67, p<0.001\right)$, and metal and plastic containers $\left(3.8 \%, \operatorname{RR} 4.4, \chi^{2} 7.38, p<\right.$ $0.001)$. Larval emergence data indicated $99 \%$ of the larvae were Ae. aegypti and $1 \%$ was Ae. albopictus.

\section{Survival of fish}

Data on fish survival are summarized in Table 4. In all villages studied, a nearly $100 \%$ fish survival rate was observed after one week of fish release. However, the rate varied in the respective villages in the one-month post-fish release. In Domatmari, the rate was $86.04 \%$ (95\% CI: 78.1-94.6\%, $p=0.27$ ), 33.7\% in Srinivaspura (95\% CI: $23.7-42.3 \%, p<0.001$ ) for Poecilia and only 16.03\% (95\% CI: 11.4-23.8\%, $p<0.001$ ) in Balmanda for Gambusia.

\section{Impact on Aedes larval populations}

Mean larval densities of Aedes (per dip) at the baseline in Domatmari, Srinivaspura and Balmanda were 9.2 (95\% CI: 7.4-12.2), 10.6 (95\% CI: 7.8-14.4) and 14.3 (95\% CI: 11.2-16.4), respectively. In all villages, no larvae were detected one-week post-fish release. After one month of intervention the mean larval densities were 0.2 (95\% CI: 0.08-0.4, $p>0.001$ ) in Domatmari, 7.8 (95\% CI: 4.8-9.7, $p<0.05$ ) in Srinivaspura and 11.7 (95\% CI: 8.5$14.1, p<0.05)$ in Balmanda.

\section{Impact on Aedes larval breeding}

The impact of larvivorous fish on Aedes larvae is summarized in Figure 1. In Domatmari, 240 containers within122 houses were checked during the baseline survey. Similarly, 86 containers within 31 houses were checked in Srinivaspura, and 130 containers within 78 houses were checked in Balmanda. Considering BI as an important parameter, IEC alone did not effectively 
Table 1 Knowledge, Attitude and Perception (KAP) on chikungunya in villages in Tumkur District, Karnataka, India, March 2006

\begin{tabular}{|c|c|}
\hline Questionnaire & Respondents $(n=50)$ \\
\hline 1. Do you know about the fever in your area? & $\begin{array}{l}\text { Yes-39 (78.0\%) } \\
\text { No-11 (22.0\%) }\end{array}$ \\
\hline 2. Do you know what causes this fever? & $\begin{array}{l}\text { No-36 }(72.0 \%) \\
\text { Dengue fever -3 (6.0\%) } \\
\text { Dirty air -1 (2.0\%) } \\
\text { Rats-1 (2.0\%) } \\
\text { Mosquitoes-9 (18.0\%) }\end{array}$ \\
\hline 3. Do you know that mosquitoes spread this fever? & $\begin{array}{l}\text { No-39 }(78.0 \%) \\
\text { May be- } 2(4.0 \%) \\
\text { Yes-9 }(18.0 \%)\end{array}$ \\
\hline 4. What do you do when someone in your family gets this fever? & $\begin{array}{l}\text { Go to hospital-48 (96.0\%) } \\
\text { Not certain- } 2(4.0 \%)\end{array}$ \\
\hline 5. What do you think is the cure for this fever? & $\begin{array}{l}\text { Control mosquitoes-1 (2.0\%) } \\
\text { Medicine-46 (92.0\%) } \\
\text { Drinking water- } 1(2.0 \%) \\
\text { Do not know-2 (4.0\%) }\end{array}$ \\
\hline 6. Do you know where these mosquitoes breed? & $\begin{array}{l}\text { Stagnant dirty water-33 (66.0\%) } \\
\text { Cracks in walls-1 }(2.0 \%) \\
\text { Earth and air }-1(2.0 \%) \\
\text { Do not know- } 15(30.0 \%)\end{array}$ \\
\hline 7. What are the water storage facilities in your house? & $\begin{array}{l}\text { Cement tanks-33 }(66.0 \%) \\
\text { Metal/Plastic containers-9 (18.0\%) } \\
\text { Earthen pots- } 7 \text { (14.0\%) } \\
\text { Overhead tanks-1 (2.0\%) }\end{array}$ \\
\hline 8. Do you cover them? & $\begin{array}{l}\text { Yes-39 }(78.0 \%) \\
\text { Sometimes-2 (4.0\%) } \\
\text { No-9 }(18.0 \%)\end{array}$ \\
\hline 9. How often do you clean and dry the containers? & $\begin{array}{l}\text { Less than } 1 \text { week-33 (66.0\%) } \\
\text { More than } 1 \text { week -14 (28.0\%) } \\
\text { Non-response-3 }(6.0 \%)\end{array}$ \\
\hline 10. How do you protect yourself from mosquito bites in day and night? & $\begin{array}{l}\text { No protection-24 (48.0\%) } \\
\text { Protection*-26 (52.0\%) }\end{array}$ \\
\hline 11. Do you know that fish can control mosquito larvae? & $\begin{array}{l}\text { Yes - } 4(8 \%) \\
\text { No }-46(92 \%)\end{array}$ \\
\hline 12. Will you co-operate if we introduce control measures? & Yes-50 (100.0\%) \\
\hline
\end{tabular}

*Protection measures-Coils, nets, fans, Neem (Azadirachta indica) smokes.

Table 2 Responses of post-IEC after fish introductions in villages in Karnataka, India, March to October 2006

\begin{tabular}{|c|c|c|c|}
\hline \multirow[t]{2}{*}{ Questionnaire } & \multicolumn{3}{|c|}{ Response } \\
\hline & Domatmari $(n=50)$ & Balmanda $(n=50)$ & $p$ value \\
\hline 1. Have you gained new knowledge through IEC? & $\begin{array}{l}\text { Yes - } 48(96 \%) \\
\text { No - } 2(4 \%)\end{array}$ & $\begin{array}{l}\text { Yes - } 47(94 \%) \\
\text { No }-3(6 \%)\end{array}$ & $>0.001$ \\
\hline 2. Did you know the cause of the fever outbreak? & $\begin{array}{l}\text { a. Chikungunya - } 42(84 \%) \\
\text { b. Dengue - } 8 \%(16 \%) \\
\text { c. Malaria - } 0 \\
\text { d. Brain fever (JE) - } 0\end{array}$ & $\begin{array}{l}\text { a. Chikungunya - } 39(78 \%) \\
\text { b. Dengue - } 3(6 \%) \\
\text { c. Malaria - } 4(8 \%) \\
\text { d. Brain fever (JE) - } 2(4 \%)\end{array}$ & $\begin{array}{l}\text { a. }>0.001 \\
\text { b. }<0.01 \\
\text { c. }<0.01 \\
\text { d. }<0.01\end{array}$ \\
\hline 3. Which mosquito species was responsible for the fever? & $\begin{array}{l}\text { a. Anopheles - } 3(6 \%) \\
\text { b. Aedes - } 47(94 \%) \\
\text { c. Culex - } 0\end{array}$ & $\begin{array}{l}\text { a. Anopheles - } 6(12 \%) \\
\text { b. Aedes - } 42(84 \%) \\
\text { c. Culex - } 2(4 \%)\end{array}$ & $\begin{array}{l}\text { a. }<0.01 \\
\text { b. }>0.001 \\
\text { c. }<0.01\end{array}$ \\
\hline 4. Aedes mosquitoes breed in & $\begin{array}{l}\text { a. Clean water - } 46(92 \%) \\
\text { b. Polluted water - } 4(8 \%)\end{array}$ & $\begin{array}{l}\text { a. Clean water - } 39(78 \%) \\
\text { b. Polluted water - } 11(22 \%)\end{array}$ & $\begin{array}{l}\text { a. }>0.01 \\
\text { b. }<0.01\end{array}$ \\
\hline 5 Did you like the fish-based biocontrol programme? & $\begin{array}{l}\text { a. Yes - } 44(88 \%) \\
\text { b. No - } 6(12 \%)\end{array}$ & $\begin{array}{l}\text { a. Yes - } 26(52 \%) \\
\text { b. No - } 24(48 \%)\end{array}$ & $\begin{array}{l}\text { a. }<0.001 \\
\text { b. }<0.001\end{array}$ \\
\hline 6. What are the drawbacks of such programme? & $\begin{array}{l}\text { a. Bad smell - } 4(8 \%) \\
\text { b. Fish died - } 2(4 \%)\end{array}$ & $\begin{array}{l}\text { a. Bad smell - } 34(72 \%) \\
\text { b. Fish died - } 31(62 \%)\end{array}$ & $\begin{array}{l}\text { a. }<0.001 \\
\text { b. }<0.001\end{array}$ \\
\hline 7. Would you promote such programme? & $\begin{array}{l}\text { a. Yes - } 50(100 \%) \\
\text { b. No - } 0\end{array}$ & $\begin{array}{l}\text { a. Yes - } 32(64 \%) \\
\text { b. No - } 18(36 \%)\end{array}$ & $\begin{array}{l}\text { a. }<0.01 \\
\text { b. }<0.001\end{array}$ \\
\hline
\end{tabular}


Table 3 Baseline Aedes larval surveys in villages in Karnataka, India, March and July 2006

\begin{tabular}{lllll}
\hline Type of breeding habitats & \% Breeding contribution & RR value & $\boldsymbol{\chi}^{\mathbf{2}}$ (df) & $\boldsymbol{p}$ value \\
\hline Indoor Cement tank & 86.9 & 8.2 & $6.74(3)$ & $<0.001$ \\
Earthen pots & 16.8 & 6.7 & $8.32(3)$ & $<0.001$ \\
Outdoor Cement tank & 8 & 3.2 & $8.76(3)$ & $<0.001$ \\
Metal and plastic containers & 3.8 & 4.4 & $7.38(3)$ & $<0.001$ \\
\hline
\end{tabular}

RR: Relative risk, df: degree of freedom.

control larval breeding in indoor cement tanks in Domatmari [odds ratio (OR): $0.54, p=0.067$ ]. Very significant evidence of improved larval control was observed in the one-week and one-month post-Poecilia release + IEC periods (OR: 1.96 and 1.58, $p<0.001$ ). In Srinivaspura (Poecilia alone), no such improvement was observed one-month post-Poecilia release (OR: 0.45, $p=$ 0.073) after a significant improvement in the one-week period (OR: 1.63, $p<0.001$ ). In Balmanda, Gambusia + IEC proved effective up to the one-week period (OR: $2.18, p<0.001$ ), but did not sustain larval control onemonth post-fish release resulting in additional Aedes breeding (OR: 0.51, $p=0.069$ ).

\section{Impact on the disease}

In the baseline survey, a total of 816 fever cases showing chikungunya symptoms were recorded in Domatmari, while 226 cases were identified in Srinivaspura and 432 cases in Balmanda. After one month of intervention only one case (reduction 99.87\%) in Domatmari, 78 cases $(65.48 \%)$ in Srinivaspura, and 136 cases (68.51\%) in Balmanda were recorded.

\section{Discussion}

Before the study began, more than 3000 cases of fever were reported in villages within the Tumkur and Kolar Districts. Subsequent laboratory investigations confirmed these outbreaks were caused by chikungunya [2]. Thus, the present study was devised to identify an alternative method of vector control, as no other immediate options were available. Accordingly, we decided to use larvivorous fish as a biocontrol method against Aedes larvae as this was found very effective against malaria vectors $[4,6]$. While we ensured matched control villages were included in our study as per standard experimental protocol, during the course of the trial, participants within the control villages released fish into their tanks when they discovered that the fish were responsible for controlling on-going outbreaks in the study villages. Thus, after consulting a statistician, the impact of intervention was assessed considering the data before and after fish introductions.

Self-sustained populations of Poecilia and Gambusia are the most preferred poeciliid larvivorous fish in malaria control in India $[4,6]$. Besides their predatory nature, the presence of such fish may also inhibit Ae. aegypti oviposition in domestic containers [7]. Maintaining these fish in confined habitats is important in an Aedes control programme. In the one-week post-fish release period, an almost $100 \%$ fish survival rate was recorded in all villages. In the following one-month period, fish populations were better sustained in Domatmari than in Srinivaspura and Balmanda.

Poecilia is an omnivorous species that better survives in confined habitats, namely open dug wells. In the absence of larvae, this fish can survive on other food available within the ecosystem. It also grows equally well in small containers with minimum care. In the malaria control programme we observed that villagers offered cooked rice or Ragi (a type of millet locally grown) as a food supplement, which helped to sustain and propagate their fish populations. This information was further told to the villagers as part of the IEC programme. In contrast, Gambusia is a cannibalistic species that feeds on zooplankton as its preferred food source, and populations of this fish are not sustained in small water bodies for long periods of time [8]. This was possibly one of the reasons that this fish did not survive

Table 4 Sustainability of larvivorous fish in villages in Karnataka, India, March to October 2006

\begin{tabular}{|c|c|c|c|c|}
\hline \multirow[t]{2}{*}{ Village } & \multirow[t]{2}{*}{ Number of tanks released fish } & \multicolumn{3}{|c|}{ Number of tanks checked/fish present (\%) } \\
\hline & & After one week & After one month & $p$ value \\
\hline Domatmari & 482 & $\begin{array}{l}178 / 176(98.8) \\
{[95 \% \text { Cl 96.3-99.4) }}\end{array}$ & $\begin{array}{l}172 / 148(86.04) \\
{[95 \% \mathrm{Cl} 78.1-94.6]}\end{array}$ & 0.27 \\
\hline Srinivaspura & 32 & $\begin{array}{l}26 / 25(96.1) \\
{[95 \% \text { Cl 94.3-98.4] }}\end{array}$ & $\begin{array}{l}27 / 8(33.7) \\
{[95 \% \mathrm{Cl} 23.7-42.3]}\end{array}$ & $<0.001$ \\
\hline Balmanda & 337 & $\begin{array}{l}126 / 124(98.4) \\
{[95 \% \text { Cl 96.1-99.2] }}\end{array}$ & $\begin{array}{l}131 / 21(16.03) \\
{[95 \% \mathrm{Cl} 11.4-23.8]}\end{array}$ & $<0.001$ \\
\hline
\end{tabular}

Cl: Confidence Interval. 

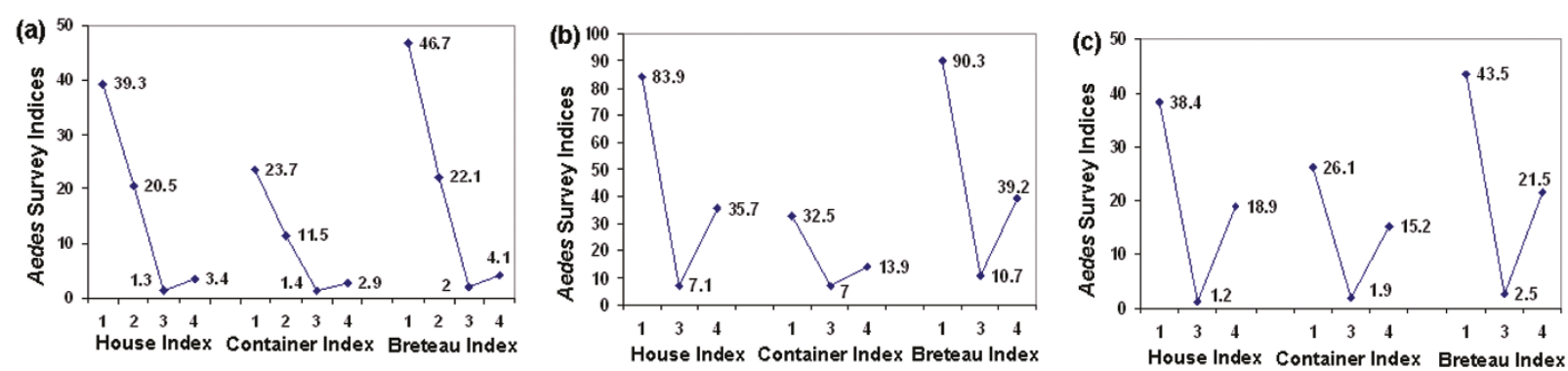

1. Baseline Aedes indices. 2. Aedes indices in post-IEC period in Domatmari. 3. One-week post-fish period. 4. One-month post-fish period

(a) Impacts of IEC followed by IEC + Poecilia in Domatmari, Tumkur District. A total of 122 houses and 240 containers were checked. HI: 1 vs. 2 : OR 0.52, $p=0.068 ; 1$ vs. 3: OR 2.22, $p<0.001 ; 1$ vs. 4: OR 1.81, $p<0.001$. Cl: 1 vs. 2 : OR 0.58, $p=0.064 ; 1$ vs. $3:$ OR $1.54, p<0.001$; 1 vs. 4 : OR 1.27, $p<0.001$. BI: 1 vs. 2 : OR $0.54, p=0.067 ; 1$ vs. $3:$ OR $1.96, p<0.001 ; 1$ vs. 4 : OR $1.58, p<0.001$.

(b) Impacts of Poecilia without IEC were assessed in Srinivaspura, Tumkur District. A total of 31 houses and 86 containers were checked. HI: 1 vs. 3: OR 1.69, $p<0.001 ; 1$ vs. 4: OR 0.41, $p=0.082$. Cl: 1 vs. $3:$ OR 1.78, $p<0.001 ; 1$ vs. 4: OR 0.48, $p=0.071$. BI: 1 vs. 3 : OR 1.63, $p<0.001$; 1 vs. 4: OR $0.45, p=0.073$.

(c) Impacts of IEC + Gambusia were assessed in Balmanda, Kolar District. A total of 78 houses and 130 containers were checked. HI: 1 vs. 3: OR 2.16, $p<0.001$; 1 vs. 4: OR 0.56, $p=0.066$. Cl: 1 vs. 3: OR 2.24, $p<0.001 ; 1$ vs. 4: OR 0.58, $p=0.064$. BI: 1 vs. 3: OR 2.18, p<0.001; 1 vs. 4 : OR $0.51, p=0.069$.

Figure 1 Impact of poeciliid larvivorous fish against Aedes aegypti larvae in indoor cement tanks in villages in Karnataka, India, March to October 2006.

even for a month in cement tanks. Thus, Gambusia is not a preferred fish in small water habitats, and is preferable for large water bodies such as ponds and lakes [6]. While Poecilia reproduced in some of the study tanks, indicating sufficient conditions for sustained populations in these containers, this was not observed for Gambusia. We have also observed this finding in the laboratory (unpublished observation).

Many biocontrol agents have been tested against Aedes larvae. Recent experience in Vietnam has been remarkably successful, with members of the community being closely engaged in vector control efforts by cleaning public areas and using biocontrol agents in water storage tanks [9]. There is an abundance of local Mesocyclops spp. (copepods) in Vietnam that can be incorporated into specifically designed community-based control programmes aided by Micronecta water bugs and fish [10]. In a village in French Polynesia, Mesocyclops aspericornis and poeciliid fish released in ponds and tanks successfully controlled mosquito species other than Aedes, which do not breed in these habitats [11]. In a coastal village in Taiwan, integrated control of Aedes used G. affinis, P. reticulata, Tilapia mossambica and Sarotherodon niloticus in potable water containers. They were later replaced with Cyprinus carassius because of constant availability and adaptability [12]. In 1980, Chinese catfish was used to control Ae. aegypti larval breeding when a dengue outbreak occurred in fishing villages among Chinese coastal provinces [13]. In
Thailand, the most effective method of Ae. aegypti control was maintaining fish in rectangular tanks and correctly covering water storing containers with lids [14]. In Southern Mexico, five indigenous fish species, namely Lepisosteus tropicus, Astyanax fasciatus, Brycon guatemalensis, Ictalurus meridionalis and P. reticulata, were significantly effective as biocontrol agents against $A e$. aegypti larvae in water storage tanks [5]. More recently, the Dengue Control Programme in the northeastern Brazilian state of Ceará has used five non-native larvivorous fish species (Betta splendens, Trichogaster trichopteros, Astyanax fasciatus, P. sphenops, and $P$. reticulata) to combat Ae. aegypti larval infestation [15]. Another example was reported in Cambodian villages, where $P$. reticulata reduced dengue-carrying Ae. aegypti larval infestation by $79 \%$, compared to control villages [16].

\section{Water tanks and water storing practices}

In each village, water is supplied via a deep bore well system operated by the local Gram Panchayats. Due to irregular water supplies, the villagers store water in indoor cement tanks for washing, bathing and also for drinking. Aedes mosquitoes mainly breed within these tanks. On an average $2.6 \pm 0.6$ (range $0-6$ ) indoor cement tanks were recorded in each household. Twothirds of villagers cleaned their tanks once in a week (as per the KAP survey), and IEC alone did not reduce the level of Aedes larval breeding. This is because of a faulty 
design in these tanks, in which the base of each tank is lower than the ground level making it difficult to completely empty. A few inches of water is retained at the bottom of the tanks, allowing Aedes larvae to rest at the bottom during the cleaning of mosquito-positive tanks. Moreover, each tank is attached to an oven for heating water for bathing (Figure 2). This helps maintain a favourable temperature range of $24-26^{\circ} \mathrm{C}$, which is conducive for the growth and development of mosquito larvae, especially Aedes. Other breeding habitats, namely outdoor cement tanks that were placed under shades for cattle feeding, small plastic containers, and earthen pots where fish could not be introduced, also supported Aedes larval breeding. This knowledge was conveyed to villagers through IEC campaign in an effort to prevent larval breeding (Figure 3).

Currently, commercially available plastic moulded mosquito-proof water storage tanks may be used for the prevention of mosquito breeding (Figure 4). One-month observations provided by our study suggested that Poecilia introductions in water storage tanks combined with IEC is an alternative method of Aedes control. IEC improved the survival and handling of this fish at the community level. This was not observed when using Gambusia. Poecilia are available in many villages in Karnataka used in the malaria control programme, and can be easily grown in wells and small tanks. Furthermore, the local religious trust propagated Poecilia in their garden tanks and helped supply them to the local villagers. After completion of the trials, Poecilia was reintroduced after IEC in Srinivaspura and Gambusia was replaced with Poecilia in Balmanda for control of Aedes larvae.

During the control programme, a weekly application of an organophosphorus compound (Temephos; 1 ppm per litre) is recommended for the control of Aedes

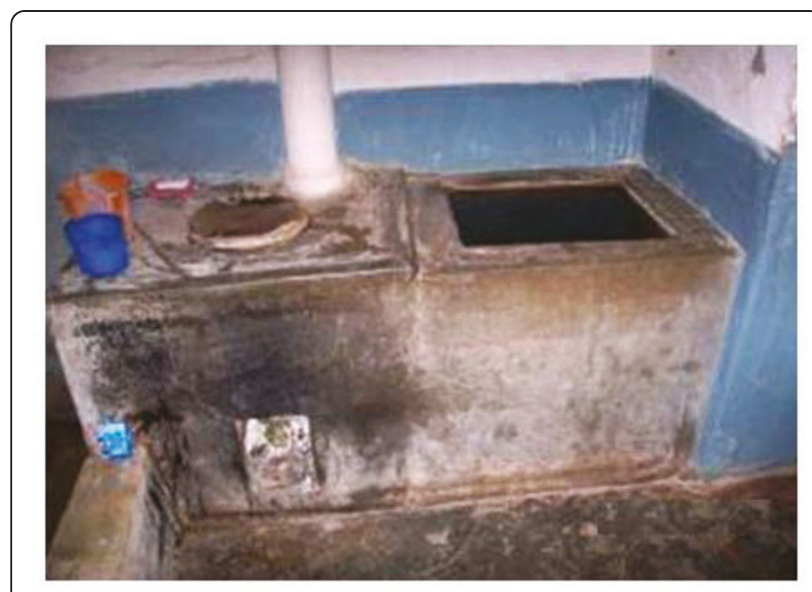

Figure 2 An example of an indoor cement tank attached to an oven for heating water. Water temperature in such tanks is maintained at $24-26^{\circ} \mathrm{C}$, which is favourable for Aedes larval breeding.

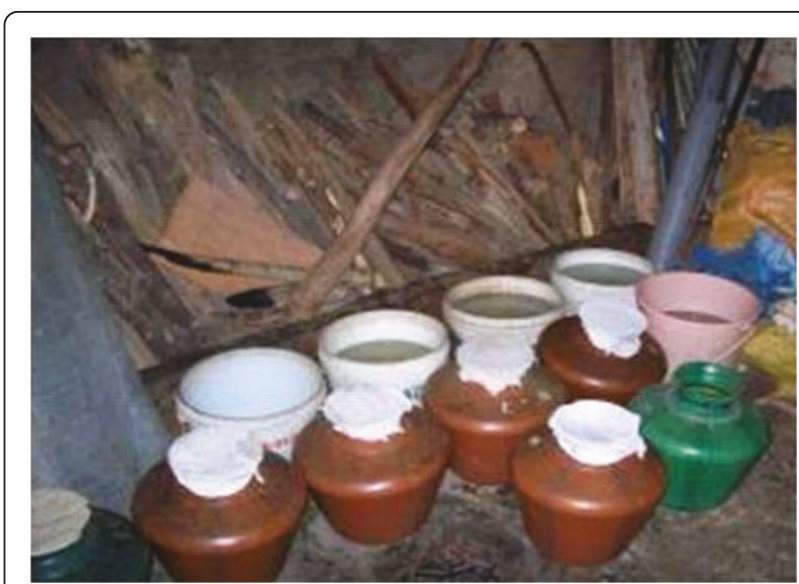

Figure 3 Villagers covered their water containers after the IEC campaign, thereby preventing Aedes from larval breeding.

larvae in potable water. Being a chemical insecticide, this is not liked by many and is logistically difficult to use including its prohibitive costs. Moreover, Aedes can potentially develop resistance to this compound if used for a long period, as reported in Brazil after 30 years of its use [17]. Larvivorous fish are therefore suggested as the best option for controlling Aedes larval infestation, as they are both sustainable and cost effective. The operational cost was calculated at 0.50 (US\$ 0.011, 1 US

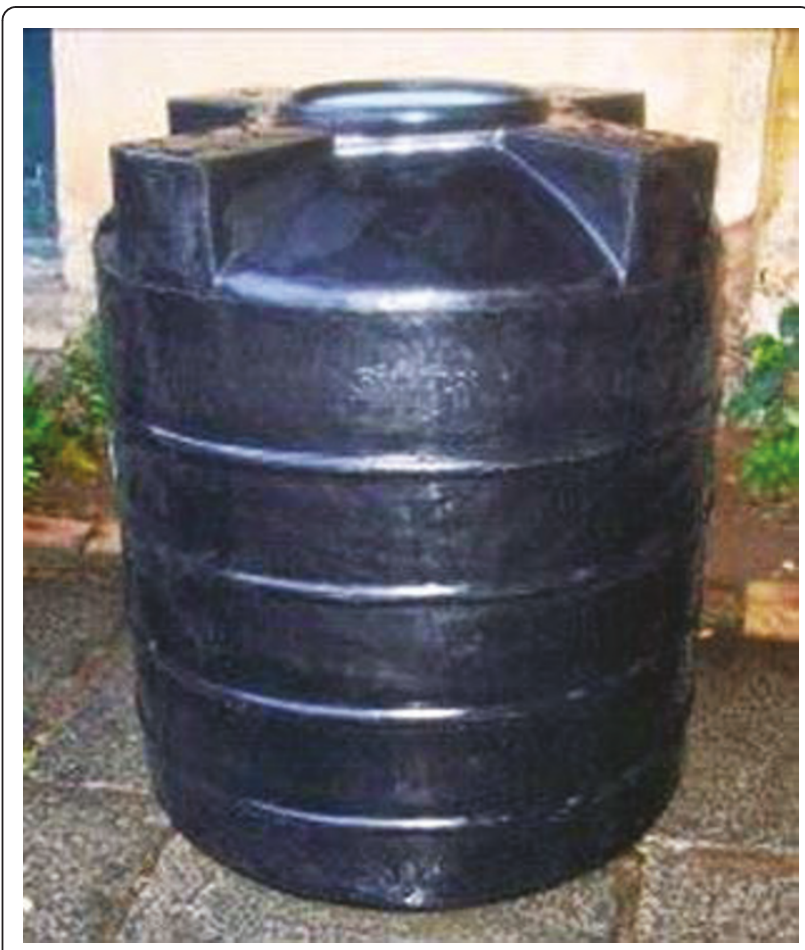

Figure 4 Commercially available plastic moulded mosquitoproof water storage tank. 
$\$=47)$ per capita per application. Thus, monthly monitoring and application of Poecilia may be recommended after proper IEC. Consequently, the community is likely to facilitate the long-term control of mosquitoes, thereby preventing the diseases transmitted by these vectors.

\section{Conclusions}

Our study successfully determined the comparative efficacy of artificially maintaining populations of two nonnative fish to control mosquito vectors. The use of Poecilia + IEC is further highly recommended for areas still affected by chikungunya in Karnataka [18], while Gambusia should be avoided as populations of this species are not sustained in domestic containers. Effective Aedes control should be formulated on the basis of local situations. Therefore, day-to-day water storing practices, 'vector sanitation' involving the National Rural Health Mission, the Gram Panchayat, and local community are essential for a successful and sustainable programme.

\section{Endnote}

${ }^{1}$ taluka is a secondary revenue division of a district.

\section{Acknowledgements and Funding}

The authors are grateful to the local health administrations, local Gram Panchayat members, the local community, the staff of National Institute of Malaria Research, Bangalore Field Unit for timely technical assistance, and the Swami Vivekananda Integrated Rural Health Centre, Pavgada for providing all necessary assistance during the survey. The authors are also thankful to Dr. Ravi Narayan, Community Health Cell, Bangalore for his guidance; to Mr. K.P. Suresh, National Institute of Animal Nutrition and Physiology, Bangalore for analysis of the data. Financial assistance from the Indian Council of Medical Research, New Delhi is gratefully acknowledged. Special thanks are also given to the two reviewers for their suggestions that considerably improved the manuscript.

\section{Author details}

${ }^{1}$ National Institute of Malaria Research (ICMR), Poojanahalli, Kannamangala Post, Devanahalli, Bangalore-562110, Karnataka, India. ${ }^{2}$ Bangalore Medical College and Research Institute, Bangalore-560002, Karnataka, India. ${ }^{3}$ Office of the District Health and Family Welfare Services, District Tumkur 572101, Karnataka, India. ${ }^{4}$ World Health Organization, South East Asia Regional Office, Indra Prastha Marg, New Delhi-110002, India.

\section{Authors' contributions}

SKG, ST and VPO conceived and arranged the entire programme. PC, SP and PK conducted the KAP survey and monitoring. SKG, ST, VPO and MR carried out entomological studies and fish release. APD reviewed and edited the paper. SKG assisted in data analysis. All authors helped write, read, and approved the final manuscript.

\section{Competing interests}

The authors declare that they have no competing interests.

Received: 13 June 2011 Accepted: 28 July 2011 Published: 28 July 2011
2. Yergolkar PN, Tandale BV, Arankalle VA, Sathe PS, Sudeep AB, Gandhe SS, Gokhle MD, Jacob GP, Hundekar SL, Mishra AC: Chikungunya outbreaks caused by African genotype, India. Emerg Infect Dis 2006, 12:1580-1583.

3. National Vector Borne Disease Control Programme (NVBDCP): Chikungunya in India in 2006. Directorate General of Health Services, Ministry of Health \& Family Welfare Services, Government of India, New Delhi 2006.

4. Ghosh SK, Dash AP: Larvivorous fish against malaria vector: a new outlook. Trans R Soc Trop Med Hyg 2007, 101:1063-1064.

5. MartiNez-Ibarra JA, Arredondo-Jiménez JI, Rodríguez-López MH: Indigenous fish species for the control of Aedes aegypti in water storage tanks in Southern Mexico. Biocontrol 2002, 47:481-486.

6. Ghosh SK, Tiwari SN, Sathyanarayan TS, Sampath TRR, Sharma VP, Nanda N, Joshi H, Adak T, Subbarao SK: Larvivorous fish in wells target the malaria vector sibling species of the Anopheles culicifacies complex in villages in Karnataka, India. Trans R Soc Trop Med Hyg 2005, 99:101-105.

7. Pamplona LGC, Alencar CH, Lima JWO, Heukelbach J: Reduced oviposition of Aedes aegypti gravid females in domestic containers with predatory fish. Trop Med Int Health 2009, 14:1347-1350

8. Sharma VP: Role of fishes in vector control in India. Larvivorous Fishes of Inland Ecosystems Malaria Research Centre (ICMR), Delhi; 1984, 1-19.

9. Kay B, Vu SN: New strategy against Aedes aegypti in Vietnam. Lancet 2005, 365:613-617.

10. Nam VS, Yen NT, Holynska M, Reid JW Kay BH: National progress in dengue vector control in Vietnam: survey for Mesocyclops (Copepoda), Micronecta (Corixidae), and fish as biological control agents. Am J Trop Med Hyg 2000, 62:5-10.

11. Lardeux FJ: Biological control of Culicidae with the copepod Mesocyclops aspericornis and larvivorous fish (Poeciliidae) in a village of French Polynesia. Med Vet Ent 1992, 6:9-15.

12. Wang $\mathrm{CH}$, Chang NT, Wu HH, Ho CM: Integrated control of the Dengue vector Aedes aegypti in Liu-Chiu village, Ping-Tung County, Taiwan. J Am Mosa Cont Assn 2000, 16:93-99.

13. Wu N, Wang S, Han G, Xu R, Tang G, Qian C: Control of Aedes aegypti larvae in household water containers by Chinese catfish. Bull World Health Organ 1987, 65:503-506.

14. Phuanukoonnon S, Mueller I, Bryan JH: Effectiveness of dengue control practices in household water containers in Northeast Thailand. Trop Med Int Health 2005, 10:755-763.

15. Pamplona LGC: Potencial de cinco espe' cies de peixe como me'todo de controle biolo' gico de larvas de Aedes aegypti, em condic, $0^{\sim}$ es de laborato' rio, no Ceara'. MS thesis Federal University of Ceara', Ceara', Brazil; 2006, [Personal communication].

16. Seng CM, Setha T, Nealon J, Socheat D, Chantha N, Nathan MB: Community based use of the larvivorous fish Poecilia reticulata to control the dengue vector Aedes aegypti in domestic water storage containers in rural Cambodia. J Vector Ecology 2008, 33:139-144.

17. Lima JB, Da-Cunha MP, Da Silva RC, Galardo AK, Soares Sda S, Braga IA, Ramos RP, Valle D: Resistance of Aedes aegypti to organophosphates in several municipalities in the State of Rio de Janeiro and Espirito Santo, Brazil. Am J Trop Med Hyg 2003, 68:329-333.

18. National Vector Borne Disease Control Programme (NVBDCP): Report on Chikungunya in Karnataka. Directorate of Health Services, Government of Karnataka, Bangalore, India 2009.

Pre-publication history

The pre-publication history for this paper can be accessed here: http://www.biomedcentral.com/1471-2458/11/599/prepub

doi:10.1186/1471-2458-11-599

Cite this article as: Ghosh et al: Comparative efficacy of two poeciliid fish in indoor cement tanks against chikungunya vector Aedes aegypti in villages in Karnataka, India. BMC Public Health 2011 11:599.

\section{References}

1. Pialoux G, Bernard-Alex Gaüzère, Jauréguiberry S, Strobel M: Chikungunya, an epidemic arbovirosis. Lancet Inf Dis 2007, 7:319-327. 